\title{
NOTAS SOBRE O PLANEJAMENTO NO PERÍODO JOÃO GOULART ${ }^{1}$ \\ Notes On Planning During The Presidency Of João Goulart
}

\author{
Fania Fridman \\ Universidade Federal do Rio de Janeiro - Instituto de Pesquisa e Planejamento Urbano e \\ Regional \\ fania.fridman@gmail.com
}

\section{Resumo}

Este trabalho apresenta um conjunto de observações acerca do planejamento durante o curto termo da presidência de João Goulart. Sigo aqui o pressuposto de que as medidas de caráter desenvolvimentista do Tempo Jango vinculam-se ao contexto de radicalização das forças políticas e dos movimentos sociais no país, da situação internacional (a Guerra Fria, a política de ajuda dos Estados Unidos aos países latino-americanos e a revolução cubana) como também do fortalecimento das concepções de planejamento, de democracia e de justiça social das esquerdas brasileiras.

\section{Palavras-chave}

planejamento; João Goulart; reformas de base

\begin{abstract}
This paper presents a set of observations about the planning for the short term of the presidency of João Goulart. I follow here the assumption that the measures of developmental character of "Time Jango" is tied to the context of radicalization of political and social movements in the country, the international situation forces (the Cold War, the policy of U.S. aid to Latin American countries and the Cuban revolution) as well as the strengthening of concepts of planning, democracy and social justice of the Brazilian left.
\end{abstract}

\section{Keywords}

planning; João Goulart; structural reforms

\footnotetext{
1 O presente artigo é uma versão ampliada da palestra "Planejamento urbano no período João Goulart" apresentada no III Congresso Internacional de História Urbana (Brasília, novembro de 2013).
} 
URBANA, V.6, nº 8, jun.2014 - Dossiê: Cidade e Habitação na América Latina - CIEC/UNICAMP 
Este trabalho apresenta um conjunto de observações acerca do planejamento durante o curto termo da presidência de João Goulart. Sigo aqui o pressuposto de que as medidas de caráter desenvolvimentista do Tempo Jango ${ }^{2}$ vinculam-se ao contexto de radicalização das forças políticas e dos movimentos sociais no país, da situação internacional (a Guerra Fria, a política de ajuda dos Estados Unidos aos países latinoamericanos e a revolução cubana) como também do fortalecimento das concepções de planejamento, de democracia e de justiça social das esquerdas brasileiras. ${ }^{3}$

\section{A revolução cubana}

Se logo após a tomada do poder em 1959 foram decretadas reformas no campo e no mar "porque a revolução é humilde e cristã" (Fidel Castro, apud HADDAD, 1961, p.125), ${ }^{4}$ em setembro de 1960 a Declaração de Havana afirmou que a "Revolução é dos pobres, pelos pobres e para os pobres" garantindo a todos o "direito a moradia adequada e é o Estado que tornará efetivo este direito". A Declaração de Havana também anunciou a nacionalização de todos os bancos, das usinas de açúcar e de mais de trezentas grandes empresas fazendo com que $80 \%$ da capacidade industrial passasse ao controle do governo. A Reforma Agrária expropriou e redistribuiu as maiores propriedades para camponeses (cada família de cinco pessoas recebeu 27 ha) e formaram-se centenas de cooperativas para cultivar as terras das antigas usinas.

No mês seguinte foi divulgada a Reforma Urbana pondo fim à atuação de empresas privadas nas atividades imobiliárias; transformando os inquilinos em compradores de suas moradias; ${ }^{5}$ reduzindo à metade os aluguéis urbanos e as taxas de eletricidade e de telefone; implantando um imposto para os imóveis desocupados e

\footnotetext{
2 Esta expressão se deve ao título "O Tempo Saquarema" do livro de Ilmar Rohloff de Mattos que considera o período como singular na história brasileira.

3 Inúmeras são as contribuições de economistas, sociólogos, cientistas políticos e historiadores sobre os embates travados durante o período, sobretudo aqueles referentes ao conflito entre os poderes executivo e legislativo, à organização de grupos políticos antagônicos a Jango e às proposições desenvolvimentistas. Ver, entre outros, IANNI (1971), DREIFUSS (1981) E BIELSCHOWSKY (2000).

${ }^{4}$ Depois de decorridos 27 meses, em abril de 1961 pela primeira vez a revolução foi denominada socialista por seu líder. Também se ouviu no comício na Central do Brasil (Rio de Janeiro) realizado no dia 13 de março de 1964 a referência cristã, quando João Goulart lembrou aos mais de 150 mil presentes que "o inolvidável papa João XXIII disse que a dignidade da pessoa humana exige normalmente, como fundamental, o direito do uso da terra e a obrigação de conceder propriedade para todos".

${ }^{5}$ Os locatários continuariam a pagar os aluguéis durante um número determinado de anos - segundo a idade da construção - e o Estado repassaria aos antigos proprietários somas até o máximo de 600 pesos por mês. Quanto mais antiga a construção, menor seria o período de pagamento, já que o governo revolucionário entendia que o proprietário original já teria recuperado o investimento sob a forma de renda.
} 
forçando a venda dos terrenos baldios. Além das brigadas de autoconstrução, o Ministerio de Bienestar Social organizou campanhas sanitárias nas quais também inseriase a erradicação dos bairros insalubres.

Para Haddad "a reforma urbana seria a novidade autêntica da Revolução Cubana" (1961, p. 183). Esta foi precedida por uma série de normas como a que suspendeu as ordens de despejo por 45 dias e a lei, de fevereiro de 1959, referida aos planos governamentais de construção de novas habitações pelo Instituto Nacional de Ahorro y Vivienda (INAV). Assim declarou o presidente Osvaldo Dorticós Torrado:

E nossas perspectivas futuras estão dirigidas, no essencial, a resolver, em matéria de arquitetura, estes quatros problemas fundamentais: erradicação das favelas e das moradias inabitáveis, solução para o crescimento vegetativo da população e para os conflitos da escassez de moradias, atenção às exigências do desenvolvimento industrial e às demandas dos ambiciosos planos de desenvolvimento agrícola (parte do discurso no Congresso cubano em 1959, apud SEGRE, 1987, p.41).

Em contraposição, na reunião da Organização dos Estados Americanos (Punta del Este) em agosto de 1961 os governos latino-americanos que julgaram a revolução socialista de Cuba e o comunismo como riscos ao capitalismo e à democracia receberam apoio financeiro dos EUA, através do programa Aliança para o Progresso, para a elaboração de projetos de desenvolvimento econômico, principalmente para a Reforma Agrária. Se, de acordo com Hardoy e Moreno (1972), não houve ali recomendações de levar às cidades reforma semelhante, incluíam-se entre as diretrizes para os investimentos da "revolução sem revolução" a melhoria das condições de vida das classes pobres urbanas com fornecimento de água potável e esgotamento sanitário; a eliminação do analfabetismo entre os adultos e a diminuição do déficit habitacional com a construção de moradias econômicas. ${ }^{6} \mathrm{E}$, ainda, o incentivo à industrialização, ao controle da inflação e à criação de um mercado comum latino-americano.

Em outubro daquele ano o governo dos Estados Unidos impôs o embargo e, no início de 1962, rompeu relações diplomáticas com Cuba. No entanto um de seus cidadãos, o cientista político norte-americano Joseph P. Morray, diria que "Os

\footnotetext{
6 O Centro Interamericano de Vivienda y Planeamiento (CINVA) foi um órgão de ensino, pesquisa, intercâmbio e assessoria para projetos de habitação popular e de urbanismo criado em 1952 no âmbito da OEA e de seu Programa de Cooperação Técnica (RESTREPO, 2003). A questão habitacional era o tema urbano prioritário desde o início da Guerra Fria e matéria de políticas na União Soviética, Polônia, França, Inglaterra e Chile (FRANCISCONI, 2013).
} 
acontecimentos da pequena ilha de Cuba estão influenciando no destino de homens muito além de suas costas" (MORRAY, 1962, p.113), expressando a esperança de milhões de latino-americanos no início da década de 1960 quando a revolução cubana mostrou que transformações sociais radicais eram possíveis no continente. ${ }^{7}$

\section{Desenvolvimento e planejamento}

A estratégia de desenvolvimento nacional iniciada no primeiro governo Vargas consistiu em uma perspectiva reformista que incorporava setores populares como condição sine qua non. ${ }^{8}$ A industrialização brasileira via substituição de importações, facilitada pela crise dos anos 1930 e pela Segunda Guerra Mundial, aparecia como "forma de superar a pobreza e diminuir a distância crescente entre a periferia e o centro" (BIELSCHOWSKY, 2010, p. 20) do mundo capitalista. Esta perspectiva filiava-se à da Comissão Econômica para a América Latina (CEPAL) que no início dos anos 1950 e de acordo com seu enfoque metodológico e analítico histórico-estrutural, propunha a categoria subdesenvolvimento para entender as especificidades produtivas, sociais, institucionais e de inserção internacional dos países latino-americanos. ${ }^{9}$ No entanto, havia sérios entraves à industrialização, como a pouca diversidade produtiva e a baixa produtividade. Incluindo também o aumento da pobreza urbana e o atraso institucional, estes foram os principais motivos que levaram a $\mathrm{CEPAL}^{10}$ a incorporar a proposta de

\footnotetext{
7 Ainda que diferentes posições tenham sido assumidas por grupos de esquerda brasileiros, é inegável a influência da revolução cubana no "Programa Socialista para o Brasil" da Organização Revolucionária Marxista - Política Operária (Polop), fundada em fevereiro de 1961, e na perspectiva do Partido Comunista Brasileiro (PCB) nascido em 1922.

${ }^{8}$ No período varguista a principal meta foi deslocar o eixo dinâmico da economia por meio de políticas orientadas para a industrialização e a diversificação da agricultura. Com o nacionalismo como ideologia e o Estado acima dos conflitos sociais, a administração pública desempenhou relevante papel enquanto agente da modernização, do controle da produção e do espaço mediante a criação de novos organismos ministérios, autarquias, departamentos e institutos - e a promulgação de leis e códigos (FRIDMAN, 2013).

${ }^{9}$ Ernesto 'Che' Guevara assim descreveu o subdesenvolvimento: "um anão de cabeça enorme e tórax largo é subdesenvolvido porque suas pernas fracas ou seus braços curtos não articulam com o resto do corpo. É produto de um fenômeno teratológico que Ihe deformou o desenvolvimento. É isso o que somos na realidade, nós, a que dão o nome suave de subdesenvolvidos: países coloniais, semicoloniais ou dependentes" (GUEVARA, 1962, p.172). Entendendo o desenvolvimento e o subdesenvolvimento como aspectos diferentes do mesmo processo universal, percebe-se em Guevara a influência da "teoria do desenvolvimento desigual e combinado" trotskista na qual o capitalismo deve ser interpretado como um complexo mundial.

10 Desde o final dos anos 50, HIRSCHMAN (1961) e BARAN (1964), entre diversos economistas, questionavam a análise de como o núcleo capitalista dinâmico impunha seus interesses nos países periféricos. Uma contribuição relevante da chamada Teoria da Dependência de GUNDER FRANK (1966), de CARDOSO e FALLETO (1969), e de SUNKEL e PAZ (1970) - ainda que estes autores discordem em pontos importantes -, é a responsabilidade atribuída às elites locais ao subdesenvolvimento, dada sua incapacidade de assumir um projeto nacional. Em meados da década de 1960 o modelo cepalino passou a ser criticado
} 
reformas estruturais - agrária, fiscal e financeira - no sentido de permitir o aumento do emprego e a melhoria da distribuição de renda. "Daí em diante na agenda da instituição a questão da equidade estaria associada ao desenvolvimento produtivo" (BIELSCHOWSKY, op.cit, p. 23).

Celso Furtado, pertencente ao grupo desenvolvimentista propagador das ideias estruturalistas cepalinas, entendia o subdesenvolvimento como um processo específico, cuja derrota resultaria do planejamento econômico e não de forças espontâneas, tal como previsto pela escola econômica liberal. Para Gunnar Myrdal, economista sueco que foi uma de suas influências, a administração pública desempenharia importante papel no programa de efetivação do progresso e das reformas sociais. O sistema produtivo planejado acabaria com a pobreza, a doença e a fome, entendendo que "o plano de desenvolvimento é um programa político". Tal projeto também foi explicitado, mas com outras tintas, na Doutrina Truman ${ }^{11}$ de ajuda econômica e de assistência técnica a qualquer nação onde se verificassem ameaças comunistas. Voltarei a esta "síndrome de Cuba".

Técnicos do Banco Nacional de Desenvolvimento Econômico, uma autarquia federal criada em 1952 como o órgão formulador e executor do desenvolvimento econômico brasileiro, ${ }^{12}$ introduziram a ideia de planejamento (TAVARES, 2009). Mas dado o forte debate ideológico naqueles tempos e face ao planejamento ser encarado por grupos empresariais como similar à temida planificação socialista, surgiram outros termos - projetamento e programação.

Ignácio Rangel, técnico do BNDE, cunhou a denominação "projetamento". Entenda-se projetamento como o conjunto de projetos de investimentos que faria parte das decisões do plano. Rangel que assistiu ao curso "Planejamento do desenvolvimento econômico e social" na CEPAL, também acreditava que as carências das sociedades latino-americanas deveriam receber tratamento via Estado. Analisava a questão agrária como rural-urbana, ou seja, um componente da dinâmica dos interesses do capital

pela esquerda já que a estratégia de industrialização não seria obstaculizada pelos centros hegemônicos, nem acarretaria na revolução burguesa nacional.

${ }^{11}$ A Doutrina Truman, consagrada em um discurso no Congresso norte-americano pelo presidente em 1949, era um conjunto de ações, a partir dos desígnios dos EUA, avaliadas como indispensáveis para manter e expandir o sistema capitalista fazendo frente ao comunismo.

12 O BNDE nasceu como o órgão brasileiro que daria a contrapartida aos financiamentos externos necessários ao andamento dos projetos financiados pelo Banco Mundial e pelo Eximbank a partir da definição, pela Comissão Mista Brasil-EUA, dos pontos de estrangulamento que impediam a expansão do setor privado. Deixarei este assunto para uma futura abordagem. 
(PEDRÃO, 2001), oferecendo assim uma leitura de unidade entre os setores da economia. Tal unidade tornou-se o alicerce da formulação das Reformas de Base do governo Jango. ${ }^{13}$

Em grande parte dos países latino-americanos, os progressistas concebiam a Reforma Agrária em conjunto com a Reforma Urbana como instrumentos primordiais na implementação de planos nacionais de desenvolvimento econômico e social que permitiriam a mobilização dos recursos materiais e de toda a população; a definição de uma estrutura espacial nacional a partir dos objetivos do desenvolvimento; e a integração dos planos de desenvolvimento agrícola com os planos de desenvolvimento industrial e de serviços mediante uma rede de infraestrutura para eliminar a dicotomia social e produtiva entre o campo e a cidade (HARDOY e MORENO, 1972).

Na difusão do ideário onde o Estado, enquanto principal agente da modernização e da democratização, implantaria políticas econômicas planejadas como estratégia de desenvolvimento nacional, foi fundamental o papel desempenhado pelo Instituto Brasileiro de Estudos Sociais e Políticos (IBESP). Criado em 1952 no âmbito do Ministério da Educação e transformado em 1955 em Instituto Superior de Estudos Brasileiros, o ISEB além de publicar os "Cadernos do Povo Brasileiro" tinha como objetivos o ensino das ciências sociais no intuito de propor soluções para os problemas do país. ${ }^{14}$ Segundo Álvaro Vieira Pinto, filósofo e membro atuante do ISEB, "sem ideologia do desenvolvimento não há desenvolvimento nacional" (PINTO, 2006, p.80) e "(...) a ideologia do desenvolvimento tem necessariamente de ser um fenômeno de massas" (PINTO, 1956, p.81). Pode-se afirmar que esta ideologia corresponde à do planejamento ao definir desenvolvimento como

um processo que encontra a sua definição na finalidade a que se dirige. (...) uma concepção geral (geral, não abstrata) de que decorrem linhas inteligíveis de ação prática rigorosa. Com efeito, sabendo que a natureza do processo implica referência a um fim, os homens de ação pública, os homens de governo e todos os que exercem, em forma manifesta, a intervenção promotora na evolução da

\footnotetext{
${ }^{13}$ Rangel integrou o Grupo de Itatiaia, origem do ISEB citado adiante. Algumas informações adicionais: a primeira turma de economistas formou-se em 1947; até então economia era uma cadeira no curso de Direito. Em 1954 nasceu o Clube dos Economistas fundado por progressistas de esquerda, cujo primeiro presidente foi Celso Furtado. O Clube editou a "Revista Econômica Brasileira" para divulgação do pensamento heterodoxo.

${ }^{14}$ O ISEB foi extinto em 12 de abril de 1964. Roberto Campos, que participou do ISEB até 1958, escreveu o artigo "O planejamento do desenvolvimento econômico de países subdesenvolvidos" publicado na revista Digesto Econômico (8), abril de 1952.
}

URBANA, V.6, no 8, jun.2014 - Dossiê: Cidade e Habitação na América Latina - CIEC/UNICAMP 
comunidade, perceberão que devem, previamente a qualquer iniciativa, fixar as metas futuras permissíveis pelo estado atual (PINTO, 1956, p. 76-77).

Na década de 1950, planejamento e desenvolvimento eram, portanto, conceitos associados. Neste período de efervescência intelectual e política, o planejamento passou a ser debatido em livros, na imprensa e nos partidos políticos. Em 1958, quando o Partido Trabalhista Brasileiro aproximou-se do Partido Comunista Brasileiro e do movimento sindical, consolidou-se a discussão de propostas para vencer as contradições sociais no país, rompendo com sua condição de periferia subdesenvolvida.

No entanto, havia também uma crença que um corpo de técnicas com validade universal e independente das estruturas políticas locais, se aplicado corretamente teria o poder de atender ao interesse público. Entre as inúmeras instituições que pensavam o planejamento elaborando estudos e oferecendo cursos sobre os dilemas brasileiros, sobretudo acerca das desigualdades regionais e das lutas travadas no campo e na cidade, acha-se a Escola Superior de Guerra. Desde 1949 a ESG através da Doutrina de Segurança Nacional, ideologia nascida nos EUA durante a Guerra Fria de luta permanente e total entre o comunismo e os países ocidentais, possuía uma conduta baseada no planejamento como oposição ao planejamento central socialista e concebido como

orientação, disposição e racionalização do conjunto de ações a determinados objetivos (...) e consiste, acima de tudo, em um sistema de escolhas ou decisões, sucessivas e hierárquicas, entre alternativas distintas (COUTO E SILVA, 1955). ${ }^{15}$

Em contraposição, para a consolidação dos conceitos subdesenvolvimento, periferia e planejamento, há que ser trazido o Movimento Economia e Humanismo $(\mathrm{MEH})$, organizado na França durante a Segunda Guerra pelo dominicano Louis-Joseph Lebret. O padre Lebret, convidado para vir ao Brasil em 1947, apresentou a base teóricometodológica do Desenvolvimento Harmônico no curso Economia Humana e Planejamento Econômico, com duração de um semestre na Escola Livre de Sociologia e

\footnotetext{
${ }^{15}$ Tal concepção de planejamento urbano e regional "tornou-se um exercício extremamente útil não apenas à penetração mais fácil do imperialismo e do capital no Terceiro Mundo, mas também como um vínculo privilegiado das teorias subjacentes (...) [para] situações reais que se deseja modificar. Elas se apresentam muito mais como portadoras de um modelo a impor" (SANTOS, 1978, p. 37-38). Isto é, as rotinas e o conceito de planejamento não são neutros, "levam as marcas da história e da cultura que os produziu. (...) 0 planejamento, portanto, depende de várias práticas consideradas como racionais e objetivas, mas que, na 
Política (São Paulo), e em conferências na Associação Brasileira de Imprensa (Rio de Janeiro). ${ }^{16}$ Mas antes de tratar o impacto de suas ideias, caberia aqui um parêntese acerca do economista François Perroux, um dos mais próximos colaboradores de Lebret, e de Colin Clark, autores que influenciaram a Economia Humana.

A referência a Perroux é importante por estabelecer um elo de ligação entre a perspectiva de desenvolvimento harmônico do $\mathrm{MEH}$ e o planejamento do desenvolvimento econômico e social buscado pelos desenvolvimentistas, incluindo Celso Furtado. Furtado dizia que "O padre Lebret era uma usina" (apud BOSI, 2012) e na sua autobiografia afirma que François Perroux foi seu professor mais importante por fazê-lo pensar a economia em seu invólucro territorial. ${ }^{17}$

As pesquisas que nessa época [Perroux] realizava conduziram-no à ideia de "pólos de crescimento", de tanta repercussão alguns anos depois. Perroux procurava introduzir conteúdo econômico no espaço físico, passar da ideia de "economia externa" à de "espaço estruturado". E hierarquizava as decisões econômicas, distinguindo aquelas que expressavam uma vontade de poder. (...) Perroux também começava a teorizar nessa época sobre o que ele chamou de "unidade interterritorial", ou seja, a empresa que se organizava horizontalmente em vários países... (FURTADO, 1985, p. 35). ${ }^{18}$

RIOS (2010) também alinha o pensamento lebretiano ao de Colin Clark, economista que defendia como finalidade da atividade econômica não a produção da riqueza, mas o bem estar dos indivíduos descrevendo como indispensáveis as condições de sobrevivência, de conforto e de superação (como a vida espiritual e a arte). Verificase em Lebret a definição de quatro necessidades: pessoais; de dignidade; pessoais terciárias e coletivas. As pessoais estariam relacionadas à alimentação, vestuário,

realidade são altamente ideológicas e políticas, e é através delas que ele se desenvolve" (ESCOBAR, 2000, pgs. 211 e 221).

${ }^{16}$ Citam-se duas personalidades que mantiveram relações com Lebret. Plínio de Arruda Sampaio debateu com ele o programa da Juventude Católica Universitária e Antonio Candido declarou em entrevista: "Fiquei amigo do padre Lebret e participei um pouco do movimento Economia e Humanismo. O padre Lebret nos disse naquela ocasião uma coisa que calou fundo em mim: 'O futuro da humanidade está nas mãos dos socialistas independentes e dos cristãos convertidos ao cristianismo.' Ele fez em São Paulo notáveis palestras sobre o movimento operário e as teorias políticas para chegar à explicação da sua, que era uma espécie de socialismo cristão" (CANDIDO, 1997, p. 42).

${ }^{17}$ Inclusive seu orientador de doutorado na França, Maurice Byé, declarava-se discípulo de Perroux (que deu um curso de Economia em São Paulo em 1946). Byé veio ao Brasil para dar aulas de Economia na Universidade do Brasil (Rio de Janeiro) onde José Arthur Rios foi seu aluno. Permaneceu no país entre 1940 e 1942 quando retorna à França para lutar na Resistência.

$18 \mathrm{Na}$ Superintendência de Desenvolvimento do Nordeste (SUDENE) eram discutidos os pólos de desenvolvimento de Perroux. 
moradia, saúde, educação e demais serviços básicos; as de dignidade seriam o espaço para receber amigos (em torno de $15 \mathrm{~m}^{2}$ ) e a capacidade de compreender obras artísticas; as pessoais terciárias seriam aquelas de desenvolvimento das capacidades intelectuais e morais e finalmente as coletivas estariam vinculadas à regulação, isto é, ao planejamento.

Para a "economia libertar-se da desordem liberal" e ser regulada em função das necessidades, o método da Jeunesse Ouvrière Catholique (Juventude Operária Católica) e da Economia Humana de "ver, julgar, agir" precisou romper com a perspectiva tradicional do planejamento, qual seja, a de anunciação de princípios e de normas. Passaram a ser levados em conta os dados concretos e as expectativas, ou seja, a convergência entre pensamento e ação tornou-se o instrumento de conhecimento científico do $\mathrm{MEH} .{ }^{19}$ Aménagement du territoire, cuja tradução em português ficou consagrada como planejamento urbano e regional, significou portanto um plano de desenvolvimento integral, harmônico, levando em conta as necessidades de cada comunidade visando à elevação das condições de vida da população. Para BOSI (2012), nos anos 1950 e 1960 Lebret "fez a distinção, hoje consensual, mas que não estava ainda difundida, entre crescimento econômico e desenvolvimento na escala humana".

A Sociedade de Análise Gráfica e Mecanográfica dos Complexos Sociais (SAGMACS), fundada por Lebret ${ }^{20}$ em julho de 1947 em São Paulo como um escritório de planejamento com representações nas maiores cidades brasileiras, realizou inúmeros projetos e planos urbanos e regionais no Brasil utilizando a metodologia de levantamento das condições de vida com militância/ação. Ao pregar a Reforma Agrária na pesquisa realizada entre 1952 e 1955 pela SAGMACS com a participação de Antônio Bezerra Baltar, ${ }^{21}$ Lebret aproximou-se das teses da CEPAL. Esta aproximação redefiniu sua trajetória como "futuro perito em problemas de subdesenvolvimento e Terceiro Mundo" e

\footnotetext{
19 A Economia e Humanismo é "um compromisso em face da miséria no mundo, um ato político de misericórdia, entendida no sentido evangélico e etimológico da palavra (...)" (LEBRET apud RIOS, 2010, p. $52)$.

${ }^{20}$ Com apoio do frei Benevenuto Santa Cruz, dos professores da Escola Politécnica da USP Luiz Cintra do Prado e Lucas Nogueira Garcez, do médico José Leitos e de André Franco Montoro que presidia a Ação Católica (CESTARO, 2009). As ressonâncias do movimento Economia e Humanismo e o papel da SAGMACS no Brasil vem sendo estudados por professores e pesquisadores de nossa área disciplinar. Recomendo a leitura dos textos inaugurais de Lamparelli (1995), Leme e Lamparelli (2001); das dissertações e teses defendidas nos programas de pós-graduação e dos artigos publicados nos Anais dos Seminários de História da Cidade e do Urbanismo e nos Encontros Nacionais da ANPUR e da ANPARQ.

21 "Étude sur les conditions de développement et d'industrialisation d'Etat du Pernambouc" para a Comissão de Desenvolvimento Econômico de Pernambuco (CODEPE).
} 
os caminhos da esquerda cristã brasileira (RIOS apud VENÂNCIO FILHO, 2011, p. 43). ${ }^{22}$ É importante fazer referência aos estudos sobre as possibilidades de desenvolvimento do Estado de São Paulo realizados em 1952 onde também está presente a proposição de reforma das estruturas agrárias como base para a repartição regional e a revitalização dos municípios. Lembre-se ainda que o arquiteto Francisco Whitaker Ferreira, um colaborador direto de Lebret no Brasil, foi empossado por Jango na direção do planejamento da Superintendência da Reforma Agrária.

O caráter selvagem do capitalismo mundial, que ele [Lebret] não hesitava em chamar de "imperialismo", inspirava-lhe propostas de desenvolvimento humanizado, via planejamento democrático do Estado, reforma agrária e substanciais investimentos públicos em infra-estrutura, habitação, saúde e educação. Seus pontos de vista maduros aproximam-no das teses da Comissão Econômica para a América Latina (CEPAL), no Chile, e dos teóricos do reformismo desenvolvimentista no Brasil a partir do segundo governo de Getúlio Vargas, de quem recebe apoio graças à indicação de Josué de Castro, Raul Prebisch e Celso Furtado. Lebret foi em todo esse período a ponte entre o projeto de desenvolvimento humanizado e a esquerda cristã latino-americana (BOSI, 2007, nota 5, p. 91-92).

Cabe ainda citar o Institut International de Recherche et de Formation en vue du Dévéloppement Harmonisé (IRFED) criado pelo MEH em 1958 na França para a formação de développeurs, agentes do desenvolvimento que deveriam trabalhar com "espírito de cooperação" para "promover condições de vida mais humanas" (LEBRET, apud ANGELO, 2010, p. 31). Até 1966, 841 alunos de 67 países ali estudaram. Entre os brasileiros estiveram Antônio Bezerra Baltar, Maria Adélia Aparecida de Souza, Benevenuto Santa Cruz, José Arthur Rios ${ }^{23}$ e Francisco Whitaker Ferreira, considerados expoentes do planejamento brasileiro.

\footnotetext{
22 Sob a liderança intelectual de Alceu Amoroso Lima e a liderança política de André Franco Montoro, o "terceiro-mundismo católico" no Brasil alinhava-se, segundo RIOS (2010), com Raul Prebisch, Jacques Chonchol, Gunnar Myrdal, Albert Hirschman, François Perroux, Alfred Sauvy (autor da expressão "Terceiro Mundo"), Yves Lacoste, Georges Balandier, Bert Hoselitz e Karl Polanyi. LOWY (1989) aponta a influência da cultura católica francesa na esquerda cristã brasileira no começo dos anos 60 através do padre Lebret e do filósofo Emmanuel Mounier. Apresenta ainda como circunstâncias para a confluência entre o cristianismo e o socialismo, a aceleração do capitalismo, da urbanização, da industrialização e das contradições sociais na América Latina.

23 José Arthur Rios e Severo Gomes fizeram parte da Comissão Organizadora do Congresso Internacional de Economia Humana realizado em São Paulo em agosto de 1954.
} 


\section{Urbanismo e Planejamento urbano e regional}

O debate sobre desenvolvimento e planejamento também envolveu sociólogos, geógrafos, engenheiros, arquitetos e urbanistas. Estes profissionais dividiam-se entre duas vertentes nos anos 50 quanto à intervenção urbanística - a dos engenheiros que propunha reformar e regulamentar a cidade existente e aquela tributária ao movimento moderno da arquitetura pela transformação radical das estruturas urbanas. ${ }^{24} \mathrm{Em} 1957$, em uma conferência na cidade de Santos, o engenheiro Anhaia Mello utilizou o termo 'planejamento' no lugar de 'urbanismo', substituição que aponta para a mudança de escala da cidade para a região. Percebe-se na fala de Mello, transcrita a seguir, uma aproximação à ideia de planejamento da Economia Humana. Recorde-se que este teria convidado o padre Lebret em 1953 para um curso sobre Desenvolvimento na Faculdade de Arquitetura e Urbanismo da Universidade de São Paulo que dirigia.

(...) O planejamento tem função estratégica, arquitetura e engenharia função meramente tática. Esses três profissionais fazem planos que não são diferentes, são complementares. O plano dos planos, plano no qual todos os outros se encaixam é feito pelo planejador: planos municipais - nunca da cidade o que não tem sentido - planos estaduais, planos regionais, nacionais ou internacionais (MELLO, apud LEME, 2001, p.87).

Para Anhaia Mello "uma galáxia de técnicos deve portanto participar do planejamento: engenheiros, arquitetos, paisagistas, artistas, médicos, juristas, economistas, sociólogos, políticos" (MELLO, apud LEME, 2001, p. 89). No entanto o treinamento destes técnicos e outros assuntos foram tema de disputas no meio profissional. Verifiquemos algumas posições.

No final de abril de 1959, o Instituto Brasileiro de Administração Municipal (IBAM) realizou o Seminário sobre Metodologia do Urbanismo no Museu de Arte Moderna do Rio de Janeiro. Entre seus participantes estiveram presentes Antônio Bezerra Baltar, Harry James Cole, Hélio Modesto, Stélio de Alencar Roxo e Wit-Olf Prochnik que foram entrevistados pelo jornal Diário de Notícias. Parte destas entrevistas foi publicada na

\footnotetext{
${ }^{24}$ A proximidade das escolas de arquitetura com as dificuldades urgentes brasileiras já vinha ocorrendo desde os anos 1940 com a introdução da disciplina 'Projeto de habitação de interesse social' no currículo. Outra referência está na recomendação saída do IV Congresso dos Arquitetos, realizado em São Paulo em 1954 com mais de 400 inscritos, de criação de um Ministério de Bem Estar Social, Habitação e Urbanismo para implementação de políticas públicas para moradia e organização do território.
} 
Revista Notícias Municipais ${ }^{25}$ na matéria "O urbanismo e a profissão de urbanista". Na introdução os editores da revista afirmam que

10. a cidade tem que ser planejada com subordinação a diretrizes regionais e nacionais; $2^{\circ}$. o aspecto físico deve estar integrado em um planejamento global em que figurem, obrigatoriamente, os aspectos econômico e social no mesmo nível. (...) Ainda predomina nos meios técnicos, administrativos e mesmo universitários, o conceito de que Urbanismo é abrir ruas, fazer parques e praças, ou compor grupos arquitetônicos isolados, em pequena ou larga escala. Com o desenvolvimento de novos métodos de estudo dos problemas urbanos e regionais, em um processo dinâmico, integrando os aspectos econômico, social e físico, surgiu uma nova ciência aplicada, cuja resultante não é igual à soma de suas três partes: é uma configuração nova que propiciou o aparecimento de profissionais de nova formação cuja similitude com o urbanista de conceito antigo está apenas no nome (Revista Notícias Municipais, 1959, p. 9).

Baltar na sua entrevista reconheceu que o urbanismo - enquanto esforço para organizar a vida urbana de forma equilibrada - e o ensino para especialistas componentes das equipes polivalentes estariam na primeira infância. Explicitou ainda a necessidade de uma legislação federal atribuindo maior capacidade de intervenção dos municípios quanto ao uso e à distribuição da propriedade do solo urbano em função do interesse social. Cole reivindicou uma formação profissional adequada por meio de cursos de pós-graduação e seminários tal como teria ocorrido na Grã Bretanha. Helio Modesto, igualmente membro ativo da SAGMACS e partícipe em diversos trabalhos, criticou a inexistência tanto de uma mentalidade de planejamento na administração pública como de planos regionais. O que

deixa os profissionais do Urbanismo sem uma base em que firmar as soluções a serem propostas. (...) Entre a maioria dos profissionais o problema da conceituação do Urbanismo está superado. Todos sabem que os problemas de uma cidade não podem ser resolvidos dentro dos seus limites físicos e administrativos. (...) Sabem que é necessário abranger os fatores econômicos e sociais que determinaram o desequilíbrio urbano, relacioná-los com os fatores físicos e considerá-los num mesmo nível de importância na proposição das soluções (Revista Notícias Municipais, 1959, p. 11-12).

Ainda que não discorresse sobre o Desenvolvimento Harmônico em sua fala, insistiu na falha da capacitação dos urbanistas e na necessidade de inclusão do

\footnotetext{
${ }^{25}$ Posteriormente denominada Revista de Administração Municipal, editada até hoje. 
Planejamento Regional no currículo das faculdades de arquitetura. Por outro lado, Alencar Roxo via com otimismo a chegada em futuro próximo de "um clima propício ao planejamento", cujo primeiro passo seria dado por meio dos cursos de pós-graduação. Finalmente, Prochnik assinalou como fatores essenciais a mentalidade de planejamento na opinião pública e profissionais treinados para ocupar os cargos na administração governamental. Reconhecia na Escola Brasileira de Administração Pública e no Instituto Brasileiro de Administração Municipal indícios nesta direção. Recorde-se que estas duas instituições desempenharam papel de destaque no movimento municipalista brasileiro capitaneado pelas elites burocráticas associadas à tradição intelectual autoritária, modernizadora e ruralista da República Velha (MELO, 1993). ${ }^{26}$

Como exemplo do paradigma de planejamento que estas instituições pregavam, de regulamentação da cidade existente considerando as condições econômicas e sociais mas sem questioná-las, note-se o pronunciamento do general Severino Sombra, ${ }^{27}$ um dos representantes da Associação Brasileira de Planejamento presentes ao I Congresso Nacional dos Municípios Brasileiros (1950).

Historicamente, no campo das realizações, é no planejamento urbano, também chamado Urbanismo, que a nova técnica vai deitar raízes. Mas, enquanto o Urbanismo dos primeiros tempos preocupava-se quase apenas com o aspecto físico, a realização artística, a paisagem, o planejamento urbano atual leva em conta principalmente as condições econômicas e sociais, de modo a proporcionar a melhor vida possível aos habitantes (SOMBRA, 1950, p. 637).

Em um artigo posterior de Helio Modesto foram reiteradas algumas de suas posições, sobretudo o entendimento que a orientação da urbanização seria objeto de planejamento. Dizia que os obstáculos físicos, econômicos ou sociais dos aglomerados urbanos "estão de tal forma ligados entre si, que não podem ser considerados

\footnotetext{
26 A EBAP da Fundação Getúlio Vargas surgiu em abril de 1952 através do programa norte-americano de cooperação técnica (o Ponto IV no âmbito da USAID) com a finalidade de oferecer um curso superior em Administração Pública além do ensino do Planejamento Regional, como o que foi ministrado por John Friedmann em 1956 (Belém) pela U.S. Operations Mission to Brazil. O IBAM, de dezembro do mesmo ano, se tornaria o braço técnico do municipalismo no sentido de propiciar o desenvolvimento do "interior" do país realizando pesquisas e planos.

27 Severino Sombra de Albuquerque organizou em 1932 a Juventude Operária Católica no Ceará confiando sua direção a D. Helder Câmara. Ambos pertenceram à Ação Integralista, afastando-se posteriormente. Sombra publicou em 1948 o livro "Técnica de Planejamento", apontado como o primeiro livro em língua portuguesa sobre a temática e foi deputado federal e presidente do Partido Trabalhista Nacional (PTN). D. Helder Câmara foi bispo e depois arcebispo de Olinda, fundou a Conferência Nacional dos Bispos do Brasil em
} 
isoladamente, nem desligados dos problemas de mesma natureza, nos níveis regional e nacional" (MODESTO, 1959, p.6). Para ele o urbanismo configuraria planos que observam apenas as consequências do processo e, por estarem vinculados à ordenação volumétrica das edificações e planimétrica das vias de circulação, ignoram a vida que ali se desenrola. Se por um lado negou a simples codificação de toda a legislação municipal como planejamento, por outro enfatizou a provisão da rede de serviços de utilidade pública como elemento orientador do crescimento urbano através de um "plano de desenvolvimento da cidade". Este plano deveria também controlar os parcelamentos da terra para venda em lotes. Enfatizou ainda a desatualização do aperfeiçoamento dos profissionais $^{28}$ e criticou a inexistência de um planejamento nacional de utilização recursos naturais, de produção de energia, de localização de indústrias e de soerguimento de áreas menos favorecidas. Na citação a seguir pode-se perceber sua vinculação ao MEH ao pregar a harmonia entre as classes:

A falta de entrosamento entre a ação administrativa municipal, a iniciativa privada e a opinião pública constitui outro fator negativo do desenvolvimento de nossas cidades, crescendo em função direta do tamanho do agrupamento humano. O estabelecimento de boas relações entre estes três elementos é condição fundamental para o êxito de um planejamento (MODESTO, 1959, p. 16).

\section{Planejamento e Reformas de Base}

Como vice-presidente e presidente do Senado, João Goulart ${ }^{29}$ fez um pronunciamento nos seguintes termos:

A técnica moderna já se revela capaz de eliminar não apenas os grandes males físicos, mas também os males sociais, dos quais o maior de todos é a miséria. E para isso são necessárias reformas de base na estrutura econômico-social do País, pelas quais temos reclamado reiteradas vezes, e que dependem de esforço conjunto do Poder Legislativo e da administração pública. Senhores Senadores, no desempenho do meu mandato anterior, procurei assumir sempre o patrocínio

1952 e alinhou-se ao Movimento Economia e Humanismo. Chamava Lebret de "meu Almirante" e "mestre do desenvolvimento".

28 Segundo o Anuário Estatístico do Brasil de 1957 (IBGE) existiam no Brasil apenas três cursos de pósgraduação (especialização) em urbanismo: na Universidade de Minas Gerais (de 1950), Universidade do Rio Grande do Sul (de 1952) e na Universidade do Brasil (de 1953).

29 João Goulart, Leonel Brizola e San Tiago Dantas faziam parte do grupo de trabalhistas que, influenciados pela democracia liberal (e a vitória sobre o fascismo) da Europa do pós guerra, defendiam o Estado planejador, o patrimônio público e o crescimento econômico distributivista. Na década de 1950 caminharam em direção à esquerda contra o imperialismo norte-americano. 
das causas populares, colocar-me ao lado dos trabalhadores e dos humildes, e defender os princípios nacionalistas e os ideais de reforma social legados ao meu Partido pela palavra e pelo exemplo do imortal presidente Getúlio Vargas (Discurso de $1^{0}$ de fevereiro de $1961,41^{a}$ Legislatura, $3^{a}$ sessão legislativa).

Depois do golpe da renúncia do presidente Jânio Quadros, Jango assume o governo em setembro sob o regime parlamentarista após manobras de grupos contrários à sua "bandeira unificadora" das Reformas de Base - Administrativa, Bancária, Fiscal e Agrária. As Reformas Urbana, Educacional e Eleitoral fizeram parte do projeto janguista posteriormente. ${ }^{30}$

Roland Corbisier ${ }^{31}$ em seu livro "Reforma ou revolução" mostra que o agravamento dos desequilíbrios internos, entre os quais o crescimento das populações urbanas e a escassez e a carestia dos imóveis residenciais, exigia a transformação na estrutura econômica e social do país através das Reformas de Base. Também denominadas Reformas de Estrutura, elas permitiriam a realização das tarefas para a emancipação econômica

pelo poder público e não pela iniciativa privada, porque só o Estado tem condições e recursos para fazer o levantamento dos problemas do País, elaborar e executar os planos nacionais de desenvolvimento (CORBISIER, 1968, p. 152).

No entanto as reformas não tiveram amparo nas forças conservadoras. Segue declaração de Eugênio Gudin: ${ }^{32}$

Recorrendo mais uma vez à morfina, apelam os partidos políticos que apóiam o Sr. Tancredo Neves (ou o Sr. Goulart?) para o "slogan" das REFORMAS DE BASE, a saber, especialmente, a Reforma Agrária, a Remessa dos Lucros para o Exterior, a Lei Antitruste, às quais acrescentam a nacionalização (confisco?) de empresas de mineração e de serviços públicos. É preciso ser integralmente (não parcialmente) imbecil para acreditar que "essas reformas", quase todas desaconselháveis, aliás, possam ter qualquer influência sobre o progresso econômico ou social do País (Eugênio GUDIN, A Balela das Reformas de Base. O Globo, 18 de março de 1961 , p. 2).

\footnotetext{
30 Outras medidas associadas foram as de estender o direito de voto aos analfabetos e às patentes subalternas das forças armadas e o maior controle dos investimentos estrangeiros no país.

${ }^{31}$ O filósofo Roland Corbisier foi diretor do ISEB até 1960 quando se candidatou pelo PTB a deputado federal. Sua atuação na Câmara foi marcada pela defesa às Reformas de Base.

32 O economista Gudin, defensor dos postulados liberais, foi ministro da Fazenda no governo Café Filho. Ligado à UDN, foi crítico radical de Vargas e de Jango, vindo a apoiar o golpe de 1964.
} 
As Reformas de Base em um momento de radicalização e de politização das massas eram sustentadas pela Frente Parlamentar Nacionalista no Congresso Nacional, por movimentos sociais como a União Nacional dos Estudantes, o Comando Geral dos Trabalhadores, as Ligas Camponesas e por entidades de classe entre as quais o Instituto dos Arquitetos do Brasil (IAB) e o Clube de Engenharia. Segue trecho do discurso de posse de Hélio Mello de Almeida ${ }^{33}$ como presidente do Clube de Engenharia, em setembro de 1961:

não se constrói a não ser em clima de ordem, paz e tranquilidade. Para o harmônico desempenho de sua missão, precisa portanto o engenheiro desse clima ideal, que só se estabelece à sombra do respeito aos direitos do povo, aos preceitos constitucionais, à legalidade do regime e à plenitude das liberdades democráticas.

Apoio o governo recebeu em abril de 1962 da Associação Comercial do Rio de Janeiro e da Federação das Associações Comerciais do Brasil através de seu presidente Rui Gomes de Almeida: ${ }^{34}$

O bom-senso e equilíbrio com que o Sr. João Goulart tem conduzido o governo criaram em torno dele uma atmosfera de confiança, que se está projetando internacionalmente, como acabamos de verificar, com o sucesso de sua visita aos Estados Unidos. (...) Os resultados práticos imediatos não são suficientes para dimensionar o êxito de sua missão. (...) Agora, mais do que nunca, é necessária a união de todos os homens responsáveis deste país em torno do Sr. Presidente da República (...). Esta união deve ter em vista o apoio a uma direção determinada, que vise a implantação das verdadeiras reformas de base, reclamadas pelo País, a fim de que possa ser mantida e acelerada sua taxa de desenvolvimento. (...) Convém deixar claro que, dentro das reformas e dos reajustamentos que se fazem necessários, no momento, consideramos também que devem ser atendidas as reivindicações justas daqueles que vivem de salários (Jornal O Globo, 12 de abril de 1962, p.2).

Do lado oposto encontravam-se o Instituto Brasileiro de Ação Democrática (IBAD), fundado em 1959 para combater o "populismo de Juscelino e as influências

\footnotetext{
33 Mello de Almeida foi presidente da União Nacional dos Estudantes (1942-1943), presidiu o Clube de Engenharia (agosto de 1961- agosto de 1964), foi Ministro de Viação e Obras Públicas do governo Goulart e em 1965 foi candidato do PTB ao governo da Guanabara.

34 O Semanário, porta-voz da Frente Parlamentar Nacional, em seu número 368 (16-22 jan. 1964) mostra que Rui Gomes de Almeida já retirara a defesa ao presidente. Em 11 de março de 1964 publicou uma "Mensagem ao povo brasileiro", na qual criticava-o por sua aliança com os comunistas. Almeida foi um dos colaboradores do IPES e aprovou o golpe de 1964.
} 
comunistas" e, de acordo com seus estatutos, "fomentar o desenvolvimento da livre empresa e a promoção da assistência social", ${ }^{35}$ e o Instituto de Pesquisas e Estudos Sociais (IPES), surgido em fevereiro de 1962. Esta instituição de pesquisa financiava filmes, cursos, seminários, conferências e publicou livros, folhetos e panfletos anti-Jango. O IPES foi "um complexo político-militar (...) cujo objetivo era agir contra o governo nacional-reformista de João Goulart e contra o alinhamento de forças sociais que apoiavam a sua administração" (DREIFUSS, 1987, p. 161). ${ }^{36}$ Retornemos às proposições janguistas.

Um fato importante a ser trazido é a criação do primeiro órgão de planejamento no poder executivo. Celso Furtado, nomeado em setembro de 1962 como Ministro Extraordinário do Planejamento do gabinete parlamentarista, teve a incumbência de apresentar um plano para o país. $^{37} \mathrm{Em}$ dezembro apresentou o Plano Trienal de Desenvolvimento Econômico e Social que foi aprovado pelo Fundo Monetário Internacional, mas abandonado 5 meses após sua divulgação. Esta primeira tentativa de planejamento global (IANNI, 1971) buscava criar requisitos para que os frutos do desenvolvimento se distribuíssem de maneira mais equitativa entre a população, isto é, que os salários reais crescessem à mesma taxa da produtividade da economia e que as desigualdades regionais fossem reduzidas. A Comissão Nacional de Planejamento

\footnotetext{
35 Sob a direção da Agência Central de Inteligência (CIA) norte-americana e com recursos provenientes de companhias brasileiras e estrangeiras, o IBAD patrocinou, através de sua "subsidiária" Ação Democrática Popular, campanhas legislativas (muitas das quais vitoriosas) de candidatos contrários a Goulart; a Campanha da Mulher Democrática; a Frente da Juventude Democrática; a Resistência Democrática dos Trabalhadores Livres no RJ e o Movimento Sindical Democrático em SP. Manteve a revista "Ação Democrática" com tiragem de 250 mil exemplares, produziu programas de rádio transmitidos por 88 emissoras em todo o país além de cursos e conferências. O IBAD foi extinto após uma Comissão de Inquérito do Congresso em 1963.

${ }^{36}$ O IPES se ligou à Escola Superior de Guerra e aos generais Golbery do Couto e Silva, Heitor de Almeida Herrera, entre tantos da ativa ou reformados (MONIZ BANDEIRA, 1977) e contou com o amparo de empresários e de partidos políticos (União Democrática Nacional e Partido Social Democrático). Manteve contatos com a Igreja, financiou os Círculos Operários do Rio de Janeiro e de São Paulo; a Confederação Brasileira de Trabalhadores Cristãos; a União Cívica Feminina de São Paulo; o Instituto Universitário do Livro; o Movimento Universitário de Desfavelamento; a Associação de Diplomados da Escola Superior de Guerra e a Marcha da Família com Deus pela Liberdade. Em novembro de 1966 um decreto presidencial declarou o IPES como "órgão de utilidade pública". Foi desativado no Rio de Janeiro em março de 1972.

37 Em julho de 1962 havia sido estabelecido o Instituto Latinoamericano de Planificación Económica y Social ILPES, um organismo autônomo sob a égide da CEPAL como projeto do Fundo Especial das Nações Unidas. Com apoio do Banco Interamericano de Desenvolvimento e outras entidades internacionais e privados possui até hoje como finalidade "contribuir com os esforços nacionais e subnacionais orientados a melhorar a qualidade das políticas públicas e fortalecer as capacidades institucionais" através de investimentos e de serviços de capacitação, assessoria e de pesquisa sobre desenvolvimento e planejamento.
} 
(COPLAN) ${ }^{38}$ ficaria encarregada de coordenar os estudos e levantamentos necessários ao planejamento do desenvolvimento econômico e social do país, e harmonizar em planos gerais e setoriais os programas e projetos elaborados por órgãos públicos e privados.

Quanto às reformas, observemos primeiramente a Reforma Agrária enunciada no Plano Trienal - seja pela pressão da Aliança para o Progresso ${ }^{39}$ como pelo movimento dos trabalhadores rurais - que pretendia acabar com o monopólio da terra, proporcionar assistência sanitária e de saúde, habitação, educação, apoio técnico e de crédito ao homem do campo ampliando a população consumidora. Entretanto o carro-chefe das Reformas de Base era próximo, mas não semelhante à do Plano Trienal. As Ligas Camponesas, desde os anos 1940 alinhadas com o PCB, a partir de 1960 adotam uma posição política com fortes vínculos com Cuba lutando por mudanças na estrutura fundiária do país.

Incluamos aqui um breve parêntese quanto à reforma agrária para resolver impasses no campo em uma estrutura capitalista, política já implementada na Europa Ocidental e nos Estados Unidos (através do Homestead Act) durante o século XIX. No livro de Henri George "Progresso e pobreza" publicado em 1879, o autor denunciava o monopólio dos latifundiários e propunha um imposto sobre a renda da terra para corrigir o que chamou de "desordem capitalista". Defensor da propriedade coletiva dos terrenos (o solo como domínio inalienável do Estado) e de um "socialismo agrário", explicava a miséria da sociedade como resultado da concentração de terras nas mãos de poucos proprietários. George exerceu influência sobre Joaquim Nabuco que, em 1884, escreveu o artigo "Henri George. Nacionalização do solo, apreciação da propaganda para a abolição do monopólio territorial na Inglaterra". ${ }^{40}$ Neste trabalho, Nabuco discorda de parte das concepções georgistas e, no sentido de transformar o "regime territorial aristocrático" respeitando os direitos adquiridos, propõe indenização para a desapropriação de terras incultas. Esta mirada, bastante similar à reforma agrária do

\footnotetext{
38 O Conselho de Desenvolvimento organizado na presidência de Juscelino Kubitschek foi substituído pela Comissão Nacional de Planejamento no governo Quadros. No período parlamentarista do governo Goulart regulamentaram-se as atividades da COPLAN, entre elas a de definir os princípios básicos que orientariam os levantamentos estatísticos.

39 "Jango voltou a preconizar a efetivação das Reformas de Base, especialmente a Agrária. Disse que as reformas se tornam necessárias até para aplicação dos recursos provenientes da Aliança para o Progresso" (Jornal O Globo, 17 de julho de 1962, p.2).

40 Escrito na Inglaterra, foi editado no Brasil por André Rebouças, abolicionista e defensor da democracia rural.
} 
Plano Trienal de Celso Furtado, me levou a procurar obras de Nabuco em sua biblioteca particular. $^{41}$

Retornemos ao debate em 1961. Entre os dias 17 e 22 de abril realizou-se o Simpósio sobre Reforma Agrária no hotel Glória (Rio de Janeiro) cujo principal redator foi José Arthur Rios. O livro "Recomendações sobre a reforma agrária" de sua autoria foi publicado pelo IBAD no mesmo ano. Ali está dito que a questão não passaria apenas pela divisão da propriedade, mas por um conjunto de medidas em vista da criação de uma classe média rural e do uso adequado da terra (inclusive com o aporte de crédito). ${ }^{42}$

Com relação à Reforma Urbana janguista, um tema ingente discutido no Brasil desde o final dos anos 1950, esta vem merecendo atenção de diversos autores (ver, entre outros, RIBEIRO, 1986; BONDUKI e KOURY, 2007; RIBEIRO e PONTUAL, 2009), cujas análises apresentam os interesses em jogo das diversas classes sociais e os conflitos que foram travados na cena política brasileira à época. Recuperemos alguns elementos da história desta proposição no Brasil e no Rio de Janeiro.

As décadas de 1930 a 1960 foram de efervescência intelectual e política. Na cidade do Rio de Janeiro e municípios vizinhos surgem pelo menos 188 organizações de massa, das quais 114 originaram-se entre os anos 1945 e 1950 . Eram grupos femininos, associações de moradores, associações cívico-populares, centros culturais, centros democráticos e comitês distritais, próximos ou diretamente vinculados ao Partido Comunista (ver APERJ, Fundo DPS). Estes movimentos populares urbanos, muitos dos quais surgidos para apoiar a chapa JK-Jango nas eleições presidenciais de 1955, reivindicavam melhorias na habitação e nas condições de vida na cidade. Quando o governo federal organizou o Conselho Federal de Habitação em junho de 1962, o governador do Estado da Guanabara Carlos Lacerda (UDN) constituiu, em contraposição, a Companhia de Habitação do Estado da Guanabara, demitiu José Arthur Rios da Coordenação do Serviço Social, extinguiu o SERFHA ${ }^{43}$ e anunciou a "sua" reforma urbana.

\footnotetext{
${ }^{41}$ Grande parte de sua biblioteca particular encontra-se no Centro Internacional Celso Furtado localizado na sede do Banco Nacional de Desenvolvimento Econômico e Social (BNDES), no Rio de Janeiro. Pelas obras ali depositadas, pude verificar que Furtado foi seu leitor atento.

42 O IBAD em janeiro de 1961 organizou um núcleo de assistência social e educacional no engenho da Galiléia, berço das Ligas Camponesas e, com base nesta experiência, desde o início de 1962 promoveu núcleos, planos de colonização e projetos de desenvolvimento no Rio Grande do Norte, em Pernambuco e na Bahia, além de postos volantes em João Pessoa e Maceió.

${ }^{43} \mathrm{O}$ sociólogo José Artur Rios, responsável pelo MEH no Rio de Janeiro, dirigiu a pesquisa sobre favelas encomendada pelo jornal Estado de São Paulo em 1960, logo assumindo a Coordenação do Serviço Social do URBANA, V.6, no 8, jun.2014 - Dossiê: Cidade e Habitação na América Latina - CIEC/UNICAMP
} 
Será assinado hoje, às $10 \mathrm{~h}$, o convênio entre a Fundação Leão XIII e o Ponto IV, no valor de 1 bilhão de cruzeiros, para a execução da Reforma Urbana do Rio de Janeiro. O empréstimo - do Fundo do Trigo - será aplicado na construção de casas populares e na urbanização das favelas da Guanabara. O órgão estadual encarregado da execução da reforma urbana é a Fundação Leão XIII que consiste, de início, na construção de 2.250 casas (...) com financiamento de 10 anos, a juros anuais de $6 \%$, com prestações de $15 \%$ sobre o salário mínimo. 0 empréstimo do Fundo do Trigo será empregado na primeira parte da reforma, da seguinte maneira: Cr\$ 458 milhões para construção de casas em terrenos comprados pela Fundação Leão XIII e para a urbanização e saneamentos de casas populares em diversas favelas; $\mathrm{Cr} \$ 187$ milhões para a urbanização total de uma favela, provavelmente a da Vila da Penha (...); e Cr\$ 155 milhões para obras urgentes em todas as favelas do Rio. (...) A urbanização e saneamento das favelas consiste, a princípio, na conclusão de diversas obras inadiáveis e imprescindíveis, tais como água, luz, esgoto, colocação de galerias pluviais, abertura de ruas, instalações de postes e meios-fios etc. Essas obras vão ser feitas nas favelas escolhidas segundo critério de densidade de população, índice de doenças contagiosas, maior facilidade de execução dos serviços e também de boa-vontade de seus moradores (Jornal Correio da Manhã, 12 de junho de 1962, p.2). ${ }^{44}$

A Assembléia Legislativa da Guanabara aprovou no mês seguinte o projeto de lei criando o Conselho Estadual de Planejamento Urbanístico (CEPU), órgão voltado para o planejamento urbano do Estado. Em 27 de agosto de 1962 foi promulgado o decreto 911 que permitiu maior número de pavimentos nas construções desde que afastadas das divisas. ${ }^{45}$ Tal decreto acarretou em impactos no mercado imobiliário da cidade com o surgimento de grandes grupos vinculados a empresas de financiamento (FRIDMAN, 1994).

Assinale-se a conferência de José Arthur Rios proferida no IPES em 1963 sobre a "Reforma da Política Habitacional" no curso de Atualidades Brasileiras. ${ }^{46}$ Após apresentar dados de domicílios (nas cidades e no campo), de crescimento demográfico e do ritmo de

Estado da Guanabara à qual estava submetido o Serviço Especial de Recuperação de Favelas e Habitações Anti-higiênicas (SERFHA), de 1956 (PEREIRA DA SILVA, 2004). "Em vez de encarar a favela como lugar do crime a ser extirpado ou removido (como propunha a política excludente e truculenta do governador do Rio Carlos Lacerda), o trabalho de Lebret, escorado por D. Helder Câmara e pela perícia do sociólogo José Arthur Rios, procurou de modo pioneiro, entender em termos comunitários a formação daqueles aglomerados urbanos gerados pelos desequilíbrios de um país subdesenvolvido" (BOSI, 2012, p. 43).

44 O decreto 1041 (de 17/6) aprovou os novos estatutos da Fundação Leão XIII, que incorporada ao Estado dedicar-se-ia à construção de habitações de baixo custo e à remoção de favelas.

${ }^{45} \mathrm{O}$ decreto não se aplicava às zonas que tivessem fixação de gabarito de altura inferior a 4 pavimentos e aos terrenos com limite de profundidade.

${ }^{46}$ Ver Arquivo Nacional, Documentos Privados, Fundo: Instituto de Pesquisas Sociais, caixa 11, Pacote 1. 
construção de moradias, afirmou que a "sub-habitação" seria um problema urbano tornando-se indispensável a intervenção nas cidades subdesenvolvidas. E afirmou que "é portanto nas cidades que se joga hoje o destino democrático do Brasil" (p. 3) reiterando a ideia de que "a zona rural manda para as cidades os seus resíduos" (p. 6), os homens de escassa qualificação. Além das sugestões consagradas como financiamento para construções, cadastro imobiliário, reforma agrária para aumentar o poder aquisitivo das populações, medidas antiinflacionárias, bônus de habitação com 6\% a.a. para atrair a poupança privada, a remodelação da Lei do Inquilinato e a punição aos terrenos baldios, a Reforma Urbana deveria socializar progressivamente a propriedade privada apenas "em zonas da cidade antes da urbanização, a fim de assegurar à municipalidade um controle dessas áreas para efeito da renovação e zoneamento urbano" (p. 14). Para efeito do zoneamento sugeria o imposto territorial urbano como "instrumento democrático de socialização" (p.15). E finalizou:

a cidade democrática no mundo moderno é uma cidade planejada. A desordem urbana é um índice de privilégios. A favela é um atestado urbano de profundas desigualdades sociais e econômicas que terão de resultar, em curto prazo, em subversão social. Sua extinção pelo planejamento da cidade é a grande tarefa que incumbe aos democratas de nosso tempo como é sua responsabilidade a extinção das condições de servidão e exploração do homem pelo homem no campo brasileiro (RIOS, 1963, p.15).

O Instituto dos Arquitetos do Brasil (seção Guanabara), por entender que o problema da moradia não se reduzia à questão da casa proletária, sugeriu a criação de um Conselho Nacional de Habitação e a Lei da Casa Própria. ${ }^{47}$ Estas demandas tiveram grande repercussão na imprensa e foram encaminhadas aos candidatos à presidência, Adhemar de Barros, Henrique Lott e Jânio Quadros (SERRAN, 1976).

A perspectiva dos movimentos populares e de profissionais era a de tornar "o imóvel residencial acessível a todos os que residem e trabalham nas grandes cidades" (CORBISIER, 1968, p. 149) e, "à semelhança da Reforma Agrária, exige fundamentalmente a liquidação do monopólio da propriedade urbana" (idem, p. 160). Suas principais reivindicações consistiam em limitar o número de imóveis urbanos de propriedade particular com a desapropriação do excedente; desapropriar por interesse social os imóveis residenciais desocupados cuja venda às classes assalariadas seria feita

\footnotetext{
47 Com financiamento pelas sociedades comerciais com o valor das prestações reajustado pelo salário mínimo.
} 
por organismos oficiais de crédito; e a construção pelo Estado de grandes conjuntos residenciais voltados à classe trabalhadora. Tais clamores remetiam-se às medidas implantadas pela Reforma Urbana cubana.

Foi reconhecido como um "passo positivo" o estabelecimento da Comissão Nacional de Habitação (decreto 209 de novembro de 1961) que depois de 7 meses tornou-se Conselho Federal de Habitação (decreto 1.281 de 25 de junho de 1962 assinado por Tancredo Neves e André Franco Montoro). Este Conselho, subordinado ao Primeiro Ministro, possuía como atribuições "orientar e promover a política de habitação do Governo, mediante um planejamento de âmbito nacional, visando de maneira particular à habitação destinada às classes economicamente menos favorecidas"; centralizar a aplicação dos recursos destinados à moradia; indicar a criação e extinção de órgãos vinculados à política habitacional; e estimular o sistema de ajuda mútua dirigida, o treinamento de pessoal técnico habilitado e a racionalização dos processos de construção com a adoção de normas de amparo à iniciativa privada. ${ }^{48}$

"Dada a premente necessidade de seguir em direção das Reformas", o IAB manifestou-se a favor da fundação dos Ministérios da Habitação, da Saúde e da Educação e apoiou a Lei 4.132 (10 de setembro de 1962) de Desapropriação por Interesse Social para a "justa distribuição da propriedade ou condicionar o seu uso ao bem estar social na forma do art. 147 da Constituição Federal". A norma considerava de interesse social os bens improdutivos ou explorados sem relação com as necessidades de moradia, trabalho e consumo "dos centros de população" (leia-se cidades); o estabelecimento de colônias ou cooperativas de povoamento e trabalho agrícola; a manutenção de posseiros em terrenos urbanos cujas residências formassem núcleos com mais de 10 famílias; a construção de casas populares; as terras e águas "suscetíveis de valorização extraordinária" depois de obras públicas; e locais para atividades turísticas e a preservação do solo, de mananciais e reservas florestais.

No entanto, as propostas de transformação da estrutura social não poderiam omitir a dimensão territorial. O editorial do número 8 de sua revista Arquitetura ao analisar o Plano Trienal diz haver apenas uma referência à habitação - no capítulo Pré-

\footnotetext{
${ }^{48}$ A Comissão Nacional de Habitação possuía a prerrogativa de coordenar e executar a política de habitação, realizar estudos sobre habitação de interesse social, sugerir medidas de incentivo às construtoras particulares, firmar convênios com órgãos oficiais ou privados e organizar seminários e congressos sobre habitação e planejamento. Haveria uma emenda constitucional para que a indenização de imóveis urbanos desapropriados por interesse social fosse em títulos da dívida pública. Em junho de 1962 o IAB-SP realizou a URBANA, V.6, no 8, jun.2014 - Dossiê: Cidade e Habitação na América Latina - CIEC/UNICAMP
} 
investimentos para o Aperfeiçoamento do Fator Humano na parte referente à saúde. Ali a moradia acompanha a alimentação e o saneamento básico como essenciais para a eliminação das doenças. Ainda que concordando com a necessidade premente de melhoria das condições de saúde, os arquitetos entendiam que deveriam ser tomadas medidas para "disciplinar e ordenar o crescimento [caótico] dos núcleos urbanos" sob pena de implicar "em maiores despesas para a coletividade". Por entenderem que "a todo o planejamento corresponde um plano territorial", caberia substituir o urbanismo "arcaico" do zoneamento formal pelo planejamento urbano e regional para mitigar os problemas urbanos, regionais e de habitação. E como a moradia não se reduz ao teto mas sim ao hábitat, estabelecer-se-ia uma mudança de escala: da forma da casa popular para o seu espaço (ARQUITETURA, 1963, p. 2-3).

Houve importantes projetos de lei de parlamentares. Um deles foi o de n० 87 apresentado em 4 de abril de 1963 pelo deputado Floriceno Paixão (PTB/RS) que estabelecia o Plano Nacional de Habitação e instituía o Fundo Nacional de Habitação. O Plano de Habitação iria privilegiar a moradia para os trabalhadores que recebessem até o valor de 15 salários mínimos vigentes em sua região e a habitação de interesse social urbana ou rural custeada através de recursos da Caixa Econômica Federal. O Plano previa ainda o financiamento para aquisição de terrenos e para a indústria de materiais de construção, como também a assistência técnica e financeira aos municípios "cuja sede tenha população igual ou superior s 10.000 habitantes para elaboração dos respectivos Planos Diretores" (DIÁRIO DO CONGRESSO NACIONAL, abril de 1963, p. 1216). ${ }^{49}$

Face à pressão das classes populares e médias das grandes cidades brasileiras, dos movimentos urbanos, dos partidos políticos e dos sindicatos mais à esquerda, discussões acaloradas ocorreram no "Seminário de Habitação e Reforma Urbana. O homem, sua casa, sua cidade" realizado pelo IAB e pelo Instituto de Previdência e Assistência dos Servidores do Estado no hotel Quitandinha em Petrópolis (Rio de Janeiro) e São Paulo em julho de 1963. Contando com a presença de mais de 200 profissionais entre arquitetos, engenheiros, assistentes sociais, advogados, economistas, geógrafos e

$1^{\text {a }}$ Jornada Nacional de Habitação onde surgiram moções encaminhadas ao Seminário de Habitação e Reforma Urbana no ano seguinte (ARQUITETURA, n. 6, 1962).

${ }^{49}$ O Fundo de Habitação receberia a contribuição mensal de $15 \%$ do valor das folhas de pagamentos, da contribuição mensal por um ano do acréscimo sobre o aluguel residencial e 5\% sobre prêmios de sorteios, loterias e de corridas de cavalos superiores a dez mil cruzeiros. Na justificativa do projeto, Floriceno afirma que em 1960 teria apresentado o projeto 1911 para o estabelecimento de um Plano Nacional de Habitação. O projeto 87 foi arquivado em sessão de 14 de julho de 1964. 
empresários da construção civil, ${ }^{50}$ o documento final apontou o déficit de moradias como resultado das condições do subdesenvolvimento, do surto industrial não disciplinado, da urbanização vertiginosa e das arcaicas relações de produção agrárias. Recomendou para "coordenar todos os esforços necessários à correção da carência habitacional e de seus problemas de aproveitamento do território (...) a criação de um Órgão Central Federal" para "fixar as diretrizes da política habitacional e de planejamento territorial do país, através da elaboração dos planos nacionais, territorial e de habitação". E visando à maior justiça no território das cidades, "à ordenação e ao equilíbrio das aglomerações urbanas e ao fornecimento de habitações condignas a todas as famílias," exigiram-se limites ao direito de propriedade e uso do solo, a adoção de regras para cercear a especulação imobiliária, a desapropriação de terrenos sem o pagamento à vista e a participação popular nos programas. Este conjunto de medidas do Estado se consubstanciaria numa Reforma Urbana entendida como vinculada à política de desenvolvimento econômico e social, "inclusive a reforma agrária" (Documento final do SHRU, apud SERRAN, 1976). ${ }^{51}$

Neste contexto, as propostas da Superintendência da Política Urbana (SUPURB), do Conselho de Política Urbana (CONPURB) e o decreto de tabelamento dos aluguéis de imóveis foram amplamente sustentadas pelos sindicatos e organizações profissionais. Vejamos:

Um segundo projeto foi o de no 1.329 encaminhado ao Congresso em 13 de novembro de 1963 pelo deputado e arquiteto Arthur de Lima Cavalcanti (PTB-Pe). Estabelecia a Superintendência da Política Urbana para "criar condições que propiciem a expansão racional dos aglomerados urbanos, tendo em vista sua integração no processo de desenvolvimento nacional". Na justificativa, o deputado afirma a necessidade de institucionalizar o planejamento físico das cidades "de modo a entrosá-lo no esforço geral de programação da economia nacional", instaurando condições institucionais para a construção e a melhoria dos alojamentos e para o emprego da mão de obra ociosa. À SUPURB, subordinada à Presidência da República, caberia a realização de estudos e pesquisas relativas aos aglomerados urbanos; a elaboração do Plano Nacional de Urbanização e dos Planos Regionais e Setoriais; a execução dos planos diretamente ou através de convênios com entidades públicas, privadas ou pessoas físicas; o fomento à

\footnotetext{
50 Compareceram também o Ministro do Trabalho Almino Afonso, representando o Presidente, e os deputados federais Franco Montoro, Fernando Santana, Rubens Paiva e Arthur Lima Cavalcanti.

51 Consta que o documento final do SHRU seria apresentado no VII Congresso da União Internacional dos Arquitetos com o enunciado geral "Arquitetura e Subdesenvolvimento" em Havana (setembro de 1963).
} 
indústria nacional de materiais de construção, o disciplinamento do mercado imobiliário e a normatização para a descentralização do parque industrial. Por este projeto também seria instituído o Fundo Especial de Urbanização e Habitação destinado a financiar a execução dos planos. De acordo com o deputado,

com essas providências, que consideramos prévias de uma necessária reforma urbana, cremos que estarão instauradas as linhas mestres de uma política urbana no Brasil. (...) A Reforma Urbana será a segunda etapa, com a revisão, atualização e restrição mesmo ao direito de propriedade, em muitos casos responsável pela falta de ordenamento no crescimento urbano, à proporção que permite as especulações com as áreas territoriais e imóveis residenciais e nada consagra em defesa das comunidades e de seus interesses" (DIÁRIO DO CONGRESSO NACIONAL no 188 , seção I, p. 9143-44). ${ }^{52}$

Pelas mãos do mesmo deputado foi encaminhado em janeiro de 1964 o projeto de instituição do Conselho de Política Urbana (CONPURB), órgão subordinado diretamente à Presidência da República cuja competência seria elaborar as diretrizes gerais do Planejamento Físico Nacional, medida precedida por pesquisas e análises dos problemas dos aglomerados urbanos "para que se possa traçar uma correta política urbana". E conceber o Plano Bienal de Obras de Investimentos segundo as necessidades de equipamentos públicos do país. Ainda entre as suas atribuições, o CONPURB tornarse-ia um órgão consultivo dos governos estaduais e municipais em matéria de planejamento físico dos aglomerados urbanos e de suas áreas de influência, revelando-se aqui a mudança de escala do planejamento em direção às regiões metropolitanas. ${ }^{53}$ Dada a "a necessidade de unificar as atividades dos órgãos públicos", seria também da alçada deste Conselho coordenar-se com órgãos e entidades regionais, estaduais e municipais cujas atividades interessassem ao planejamento físico nacional; a promoção de cursos de formação de "planejadores físicos e outros profissionais de planejamento" para gerar uma "mentalidade de planejamento em setores governamentais e privados"; providenciar levantamentos sobre o mercado imobiliário e a situação das empresas de

\footnotetext{
52 O Fundo Especial de Urbanização e Habitação teria dotação orçamentária da União, parte da arrecadação de contribuições de melhoria provenientes de obras de saneamento e de urbanização, receita patrimonial, contribuições dos governos estaduais e municipais e juros das operações realizadas. Com a criação da SUPURB, haveria em cada Estado, território e no Distrito Federal uma Delegacia Regional que providenciaria a desapropriação de imóveis urbanos por utilidade pública ou de interesse social. O projeto foi arquivado pela Mesa Diretora depois do golpe em 12 de maio de 1964.
} 
construção civil e de materiais para obras propondo providências de ordenamento; sugerir medidas para o crédito imobiliário e elaborar planos de ajuda mútua voltados para a população de baixa renda com financiamento de longo prazo (CAVALCANTI, 1965). ${ }^{54}$

Segundo o mesmo deputado, "com o plano global urbano e traçadas as linhas mestras de uma política urbana nacional" a execução da Reforma Urbana exigiria a Reforma Administrativa; a coordenação de todos os órgãos estatais, paraestatais ou de economia mista, federais, estaduais e municipais que "interferem no equipamento urbano"; a democratização do crédito imobiliário; a atualização da Lei do Inquilinato; a criação de distritos industriais interurubanos "e das respectivas comunidades operárias"; a fundação de companhias mistas urbanizadoras nas zonas de maior adensamento metropolitano "onde fatores de conurbação exigem um plano diretor e urbano comum"; e a contribuição de melhoria para os serviços de urbanização (CAVALCANTI, 1965). ${ }^{55}$

O CONPURB, anunciado no Comício da Central do Brasil do dia 13 de março de 1964 seria assinado pelo presidente no dia 2 de abril. Em seu discurso Jango também noticiou que em poucas horas iria subscrever um decreto "que regulamentará o preço extorsivo e abominável dos apartamentos residenciais que estão desocupados, de todos que hoje afrontam e ferem o povo". O decreto 53.702, de 14 de março de 1964, fixou os valores dos aluguéis, ${ }^{56}$ cuja fiscalização seria exercida pelo Comissariado de Defesa da Economia Popular (CODEP) e pelas Delegacias Policiais competentes. O CODEP, vinculado ao Ministério da Justiça, havia sido criado em 11 de março de 1964 (decreto 53.678)

\footnotetext{
53 REIS FILHO (1996) revela que a equipe da FAU-USP havia sugerido no SHRU uma mudança na Constituição no sentido da inclusão de dispositivos para a criação das Regiões Metropolitanas, mudança à qual empenhou-se o jurista Ely Lopes Meirelles.

54 Em uma nota publicada na imprensa, o IAB-GB manifestou seu integral apoio à medida oferecendo ao Presidente "toda a colaboração dos arquitetos cariocas", pois as "proposições constantes da referida minuta de decreto representam elementos da maior significação para a solução dos angustiantes aspectos da crise habitacional e caótico desenvolvimento dos aglomerados brasileiros" (Jornal Correio da Manhã, 28 de janeiro de 1964).

55 Cavalcanti era um entusiasta do método de análise e pesquisa realizado pela SAGMACS nas favelas da Guanabara "trabalho único e extraordinário [que] deveria ser realizado com amplitude nacional, (...) é o estudo mais notável neste setor jamais realizado no Brasil" (1965, p. 357).

56 Este decreto, que excluía as habitações de alto luxo (aquelas com custo superior ao preço médio no mercado imobiliário), as chácaras e sítios das zonas urbana e suburbana, as residências com área superior a $120 \mathrm{~m}^{2}$ localizadas à beira mar, em praias de veraneio e estâncias hidrominerais, foi regulamentado pelo decreto 53.845 de 25 de março de 1964. Os valores fixados foram de até $1 / 5$ do salário mínimo local para o imóvel com um quarto; até $2 / 5$ com quarto e cozinha; até $3 / 5$ com sala, quarto e cozinha; até $4 / 5$ com sala, quarto, cozinha e dependências; até um salário com sala e dois quartos e dependências e até um salário e meio com sala, três quartos e dependências. Estes valores seriam reduzidos em $20 \%$ na zona suburbana das cidades.
} 
para realizar o levantamento dos prédios e apartamentos desocupados e enviá-lo ao Ministério da Justiça e Negócios Interiores para a tomada de providências necessárias à desapropriação por utilidade social.

O Conselho Nacional de Habitação, a Lei de Desapropriação por Interesse Social, a SUPURB, o CONPURB, o CODEP e o Tabelamento dos aluguéis, cujas características assemelhavam-se às das medidas tomadas em Cuba na direção da Reforma Urbana, provocaram imediata repercussão. Atentemos para duas reações ao congelamento dos aluguéis: a primeira antes mesmo do decreto ser assinado, na qual se pode constatar o desagrado do setor da construção civil.

O Presidente do Sindicato das Indústrias da Construção Civil do Estado da Guanabara, Sr. Félix Martins de Almeida, declarou que o incremento das construções é a única solução para o problema habitacional em todo o País, e que para tal deve ser criado um mecanismo de proteção antiinflacionária para os investimentos públicos e privados no setor. Entendemos - disse - que o tabelamento dos aluguéis acarretará paralisações na construção residencial, passando o capital a buscar, naturalmente, emprego em aplicações mais rendosas, com isso, haverá desemprego para os trabalhadores da construção civil, que na Guanabara, constitui o maior contingente operário, com cerca de 120 mil homens (Jornal O Globo, dia 19 de fevereiro de 1964, p. 12).

No Juízo da $11^{\text {a }}$ Vara Criminal foram impetrados, ontem, os primeiros três "habeas corpus" preventivos contra o Comissariado de Defesa da Economia Popular no tocante ao tabelamento de aluguéis... Os pedidos de "habeas corpus" alegam a inconstitucionalidade do decreto presidencial; argumentando que a matéria do inquilinato é regulamentada por lei, a qual não pode ser modificada por um decreto (Jornal O Globo, dia 18 de março de 1964, p. 1).

No Comício da Central do Brasil, reunindo centenas de milhares de pessoas convocadas por sindicatos, associações de servidores públicos, entidades estudantis e partidos políticos de esquerda, o presidente anunciou as medidas das Reformas de Base que dariam início às mudanças estruturais do país.

É hora das Reformas. (...) Para milhares de brasileiros, o caminho das reformas é o do progresso e da paz social. Reforma, trabalhadores, é solucionar pacificamente contradições de uma ordem jurídica superada pela realidade em que vivemos (Discurso de 13 de março de 1964). 
Se as Reformas de Base eram instrumentos fundamentais para a implementação de planos nacionais de desenvolvimento econômico e social, o golpe militar de 31 de março de 1964 destruiu "os novos tempos e as novas tarefas do povo brasileiro". ${ }^{57}$

\section{Referencias}

ANGELO, M. R. (2010). Les développeurs. Louis-Joseph Lebret e a Sagmacs na formação de um grupo de ação para o planejamento urbano no Brasil. Tese de doutorado. Programa de Pós Graduação em Arquitetura e Urbanismo, EESC/USP, São Paulo.

BARAN, P. (1964). A economia política do crescimento. Rio de Janeiro: Zahar [1957].

BIELSCHOWSKY, R. (2000). Pensamento econômico brasileiro. O ciclo ideológico do desenvolvimentismo. $4^{a}$ ed. Rio de Janeiro: Contraponto.

---. (2010). Sesenta años de la CEPAL y el pensamiento reciente. In BIELSCHOWSKY, R. (org.). Sesenta años de la CEPAL: textos seleccionados del decenio 1998-2008. Buenos Aires: Siglo Veintiuno Editores.

BONDUKI, N. e KOURY, A. P. (2007). Das reformas de base ao BNH. As propostas do Seminário de Habitação e Reforma Urbana. Anais do XII Encontro Nacional da Anpur. Belém: Anpur.

BOSI, A. (2007). Da esquerda cristã à teologia da libertação. In JINKINGS, I.; PESCHANSKI, J. A. (orgs.). As utopias de Michael Lowy. Reflexões sobre um marxista insubordinado. São Paulo: Boitempo.

---. (2012). Economia e humanismo. Estudos Avançados (75), maio/agosto.

CANDIDO, A. (1997). Entrevista. In Rememória. Entrevistas sobre o Brasil do século XX. São Paulo: Fundação Perseu Abramo.

CARDOSO, F. H.; FALLETO, E. (1969). Dependência e desenvolvimento da América Latina. Rio de Janeiro: Zahar Editores.

CARVALHO, A. C. (2013). Os jornais cariocas da rede da democracia na queda do governo Goulart. Historica (58), maio.

CAVAlCANTI, A. L. (1963). Habitação terá lei específica. Arquitetura (18), dezembro. ---. (1965). Política urbana e habitacional. Reforma urbana. Revista Civilização Brasileira (2).

\footnotetext{
57 João Goulart. Introdução à mensagem presidencial de abertura da sessão legislativa de 15 de URBANA, V.6, no 8, jun.2014 - Dossiê: Cidade e Habitação na América Latina - CIEC/UNICAMP
} 
CESTARO, L. R. (2009). A Sagmacs e o Estado da Aglomeração Paulistana. Dissertação de Mestrado. Programa de Pós Graduação em Arquitetura e Urbanismo, EESC/USP, São Paulo.

CORBISIER, R. (1968). Lógica e cronologia das reformas. In CORBISIER, R. Reforma ou revolução?. Rio de Janeiro: Civilização Brasileira.

COUTO e SILVA, G. (1955). Planejamento estratégico. Rio de Janeiro: Bibliex.

DIÁRIO DO CONGRESSO NACIONAL, seção I, abril de 1963.

DIÁRIO DO CONGRESSO NACIONAL, seção I, novembro de 1963.

DREIFUSS, R. (1987). 1964: A conquista do Estado. 5a ed. Petrópolis: Vozes [1981].

ESCOBAR, A. (2000). Planejamento. In SACHS, W. (editor). Dicionário do desenvolvimento. Guia para o conhecimento como poder. Petrópolis: Vozes [1992].

FARIA, R. S. (2009). Urbanismo e municipalismo entre a Associação Brasileira de Municípios e o Instituto Brasileiro de Administração Municipal: a construção institucional do municipalismo brasileiro pós 1946 e os problemas técnicos do urbanismo. Anais do XIII Encontro Nacional da Anpur. Florianópolis: Anpur; UFSC.

FRANCISCONI, J. G. Seminário de Quitandinha e Q+50: resultado, avaliação e desafios atuais. Disponível em: <wWw. vitruvius.com.br/revistas/read/arquitextos/14.160/4880> acesso em 1/10/2013. FRIDMAN, F. (1994). O problema habitacional do Rio de Janeiro. Cadernos IPPUR/UFRJ (2/3), set./dez.

---. (2013). Resenha do livro Urbanismo na Era Vargas: a transformação das cidades brasileiras. Revista Brasileira de Estudos Urbanos e Regionais (2), v. 15, novembro.

FURTADO, C. (1985). A fantasia organizada. Rio de Janeiro: Paz e Terra.

GOULART, J. Discurso em $1^{\circ}$ de fevereiro de 1961. Disponível em: <http://www.institutojoaogoulart.org.br/noticia.php?id=17\&busca =\&pagina=> acesso em 22/12/2010.

---. Os novos tempos e as tarefas do povo brasileiro. Introdução à Mensagem Presidencial da Sessão Legislativa de 1964. Disponível em: <www.institutojoaogoulart.org.br/upload/conteudos/120128180216_joao_goulart_mens agem_ao_co.pdf> acesso em 22/12/2010.

março de 1964.

URBANA, V.6, no 8, jun.2014 - Dossiê: Cidade e Habitação na América Latina - CIEC/UNICAMP 
GUEVARA, E. (1962). Cuba: caso excepcional? In SWEEZY, P.; HUBERMAN, L.; MORRAY, J.P.; SCHLEIFER, M., GUEVARA, E. Reflexões sobre a revolução cubana. Rio de Janeiro: Zahar Editores.

GUNDER FRANK, A. (1968). O desenvolvimento do subdesenvolvimento. São Paulo: Sinal [1966].

HADDAD, J. A. (1961). Revolução cubana e revolução brasileira. Rio de Janeiro: Civilização Brasileira.

HARDOY, J. E.; MORENO, O. A. (1972). Primeros pasos de la reforma urbana en America Latina. Revista Eure 2 (4), marzo.

HIRSCHMAN, A. (1961). A estratégia do desenvolvimento econômico. Rio de Janeiro: Fundo de Cultura [1958].

IANNI, O. (1971). Estado e Planejamento Econômico no Brasil. Rio de Janeiro: Civilização Brasileira.

INSTITUTO BRASILEIRO DE GEOGRAFIA E ESTATÍSTICA (1957). Anuário Estatístico do Brasil 1957. Rio de Janeiro: Conselho Nacional de Estatística.

LAMPARELLI, C. (1995). O ideário do urbanismo em São Paulo em meados do século XX; Louis-Joseph Lebret e a pesquisa urbano-regional no Brasil. Cadernos de Pesquisa do LAP (5), mar/abr.

LEBRET, L. J. (1963). O drama do século XX. Miséria, subdesenvolvimento, inconsciência, esperança. $2^{a}$ ed. revista. São Paulo, Livraria Duas Cidades [1960].

LEME, M. C.; Lamparelli, C. (2001). A politização do urbanismo no Brasil: a vertente católica. Anais do IX Encontro Nacional da ANPUR, v. II. Rio de Janeiro: ANPUR; IPPUR.

LEME, M. C. (2001). Urbanismo: a formação de um conhecimento e de uma atuação profissional. In BRESCIANI, M. S. (org.) Palavras da cidade. Porto Alegre: Editora da UFRGS.

LOWY, M. (1989). Marxismo e cristianismo na América Latina. Lua Nova (19), novembro. Disponível em: <http://dx.doi.org/10.1590/S0102-64451989000400002> acesso em 20/7/2013.

MATTOS, I. R. (1994). O Tempo Saquarema. A formação do Estado imperial. $3^{a}$ ed. Rio de Janeiro: Access.

MELO, M.A. (1993). Municipalismo, nation building e a modernização do Estado no Brasil. Revista Brasileira de Ciências Sociais (23), vol. 8, outubro. 
MODESTO, H. (1959). Ausência de planejamento no Brasil. Notícias Municipais (37), nov/dez.

MONIZ BANDEIRA, L. A. (1977). O governo João Goulart: as lutas sociais no Brasil (1961-1964). Rio de Janeiro: Civilização Brasileira.

MORRAY, J. P. (1962). Cuba e o comunismo. In SWEEZY, P.; HUBERMAN, L.; MORRAY, J.P.; SCHLEIFER, M.; GUEVARA, E. Reflexões sobre a revolução cubana. Rio de Janeiro: Zahar Editores.

MUNTEAL, O.; VENTAPANE, J.; FREIXO, A. (orgs.). (2006). O Brasil de João Goulart. Um projeto de nação. Rio de Janeiro: Edit. PUC-RJ; Contraponto.

O

SEMANÁRIO.

Disponível

em:

<http://www.gedm.ifcs.ufrj.br/upload/documentos/29.pdf> acesso em 15/5/2013.

O URBANISMO e a profissão de urbanista. Entrevistas (1959). Notícias Municipais (34), maio/junho.

PEDRÃO, F. C. (2001). Ignácio Rangel. Estudos Avançados (41), v. 15, jan/abr.

PEREIRA DA SILVA, M. L. (2004). A permanência das favelas cariocas e o plano Doxiadis num contexto de mudanças (1960-1965). Anais do VIII SHCU, cd-rom.

PINTO, A. V. (1956). Ideologia e desenvolvimentismo nacional. Rio de Janeiro: Ministério da Educação e Cultura.

---. (2006). Ideologia e desenvolvimento nacional. In MUNTEAL, O.; VENTAPANE, J.; FREIXO, A. (orgs.). O Brasil de João Goulart. Um projeto de nação. Rio de Janeiro: Edit. PUC-RJ; Contraponto.

PONTUAL, V. (2011). O engenheiro Antonio Bezerra Baltar. Política urbanística, Cepur e Sagmacs. Revista Brasileira de Estudos Urbanos e Regionais (1), v.13, maio.

REIS FILHO, N. G. (1996). Notas sobre a organização das regiões metropolitanas. Cadernos de Pesquisa do LAP (12), mar-abr.

RESTREPO, L. F. A. (2003). El CINVA y su entorno espacial y político. Mimesis (1), v. 24.

REZENDE, V. (org.). (2012). Urbanismo na Era Vargas: a transformação das cidades brasileiras. Niterói: Editora da UFF; Intertexto.

RIBEIRO, C; Pontual, V. A reforma urbana nos primeiros anos da década de 1960. Disponível em:<www.vitruvius.com.br/revistas/read/arquitextos/10.109/50> acesso em $30 / 6 / 2010$. 
RIBEIRO, L. C. (1986). Reforma urbana. In Abreu, H.; Ribeiro, L. C. Debatendo a reforma urbana. Rio de Janeiro: Fase.

RIOS, J. A. (2010). Lebret: profeta ou visionário. Carta Mensal (659), fevereiro. SÁ EARP, F.; PRADO, L. C. (2007). Celso Furtado. In FERREIRA, J.; AARÃO REIS, D. (orgs.). Nacionalismo e reformismo radical 1947-1964. Rio de Janeiro: Civilização Brasileira.

SANTOS, M. (1965). A cidade nos países subdesenvolvidos. Rio de Janeiro: Ed. Civilização Brasileira.

---. (1978). A divisão do trabalho social como uma nova pista para o estudo da organização espacial e da urbanização nos países subdesenvolvidos. Anais do $3^{\circ}$ Encontro Nacional de Geógrafos. Fortaleza: UFC; AGB.

SEGRE, R. (1987). Arquitetura e urbanismo da Revolução Cubana. São Paulo: Nobel.

SERRAN, J. R. (1976). O IAB e a política habitacional brasileira, 1954-1975. São Paulo: Schema Editora.

SOMBRA, S. (1950). Técnica de Planejamento. Revista Brasileira dos Municípios (11), jul-set.

SUPPO, H. (1995). Intelectuais e artistas nas estratégias francesas de "propaganda cultural" no Brasil (1940-1944). Revista de História (133).

TAVARES, M. C. (2009). Entrevista. Memórias do Desenvolvimento (3), out. VENÂNCIO FILHO, A. (2011). José Arthur Rios. RIHGB (453), out/dez.

\section{Fontes Documentais}

Arquivo Nacional - Documentos Privados, Fundo: Instituto de Pesquisas Sociais, caixa 11, Pacote 1.

Arquivo Público do Estado do Rio de Janeiro - Departamento de Polícia Política Social: $1530 ; 1531 ; 1622 ; 1532 ; 1533 ; 6-00840 ; 7-0878 ; 8-1.529$; notação 30007. Fundo: Polícia Política Setor: informações - Pasta: 59, Folha: 156; Pasta: 9 - Folha: 85; Notação 32 - IBAD; Departamento Federal de Segurança Pública - Boletim reservado n. 167 (set. 1955); n. 170 (8/9/1955); n. 171 (9/9/1955); n. 182 (12/9/1955); n. 183 (13/9/1955); Informe: $14 / 9 / 1955$ e 24/1/1956. 
Biblioteca Nacional - Jornal Correio da Manhã, edições de 13/5/1962, 14/6/1962, 2/9/1962, 11/9/1962, 28/1/1964. 28/1/1964, 14/3/1964, 15/3/1964; Jornal O Globo, edições de 5/6/1962, 12/9/1962, 7/1/1963, 18/10/1961, 12/4/1962, 17/7/1962, 21/8/1963, 2/1/1964, 6/2/1963, 16/3/1964, 18/3/1964, 19/3/1964.

Biblioteca Paulo Santos - Revista Arquitetura (Instituto dos Arquitetos do Brasil) no 5 mar/abr 1962, no 6 dez 1962, no 7 jan. 1963, no 8 fev. 1963, no 10 abr. 1963, n० 12 jun. 1963 , no 13 jul. 1963, no 14 ago. 1963, no 15 set. 1963, no 17 nov. 1963, no 18 dez. 1963, no 19 jan. 1964, n० 21 mar. 1964, no 72 jun/jul 1968. 